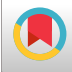

\title{
Sustained Support for a Dissertation Will Facilitate Postgraduate Research Publication: An Experience From South India
}

\author{
Praveenlal Kuttichira ${ }^{1,{ }^{*}}$, Kumudam M Unni ${ }^{1}$ and P R Varghese ${ }^{1}$ \\ ${ }^{1}$ Jubilee Mission Medical College and Research Institute, Thrissur, India
}

"Corresponding author: Jubilee Mission Medical College and Research Institute, Thrissur, India. Tel: +91-9895647935, +91-487-2432200, Fax: +91-4872421864, Email: prof.praveenlal@gmail.com

Received 2020 April 11; Accepted 2020 April 22.

\begin{abstract}
Background: Though India's position in research is notable, it is poor in medical research, barring four centers of excellence. Where the priority for the Government is providing universal health care and for a postgraduate (PG) is becoming a busy clinician, the research remains a low priority. Getting published is an incentive for researchers, and its experience during the training period will be valuable. Research by practitioners in the field is a need in low-and middle-income (LAMI) countries to find workable solutions to local problems.

Objectives: The objectives of this study were to develop a system for sustained support and evaluation of the dissertation and to examine its impact on getting published by PG students.

Methods: In this prospective study, all 27 PG students of 2015 Batch were given support throughout their six-semester course. Participants were PG students registered for the course in 2015. This included orientation for guides, research methodology (RM) for students and pre-submission (synopsis) external review in the first semester; mid second-year review in the fourth semester and pre-submission (final dissertation), and selection for award and workshop for paper submission in the fifth semester.

Results: Before appearing for the final examination in 2018, all 27 students prepared papers out of their dissertations and submitted them to the journals. From April 2019,19 papers were published, and eight were in various stages of publication.

Conclusions: Given sustained guidance and support from the institution, students perform very well, leading to improved publication status.
\end{abstract}

Keywords: Postgraduate Thesis, Dissertations, Research Publications

\section{Background}

Publication rates of medical dissertations vary from country to country; $14.4 \%$ in Cameroon (1), $17 \%$ in France (2), $17.6 \%$ in Peru (3), 23.8\% in Finland (4), and 30\% in India (5). According to the Thomson Reuters report, India ranked eleventh in the number of published papers and sixteenth in the number of citations during 2001-2011(6). Four medical colleges in India (All India Institute of Medical Sciences, New Delhi; Post Graduate Institute of Medical Education and Research, Chandigarh; Christian Medical College, Vellore; and Sanjay Gandhi Post Graduate Institute of Medical Sciences, Lucknow) that had published the highest number of papers in Medical Sciences between 2005 and 2014 are among the top ten institutions worldwide; however, around $57.3 \%$ of the Indian medical institutions (579 institutions) had no research published in the decade (7). Our medical college started in 2003 is one of those.

The factors responsible for this dismal state, some believe is due to the clinical burden, leaving less time for meaningful research. However, this is not entirely true since the largest number of high-quality publications come from institutions that serve the highest number of patients, not just in India but also all over the world (8). Moreover, in the earlier years, faculty promotions used to be time-bound, which has changed in recent years, based on the rates of research and publications. Research output is closely linked to the expenditure on research. According to a study on Asian countries, there was a positive correlation between the country's expenditure on research and development, a larger number of universities, and more number of scientific indexed journals and the research outcomes, as measured by the total number of research publications, citations per document, and H-index (9). While the budget of National Institute of Health in the US is 32 billion dollars a year, the budget of Indian Council of Medical Research, an apex body in India, is 232 million dollars (8).

Getting published is an incentive to any researcher; next best to "peak experience" of a discovery. Giving that live experience to a student before the end of the training might encourage a doctor for continuing research interest.

Copyright (c) 2020, Journal of Medical Education. This is an open-access article distributed under the terms of the Creative Commons Attribution-NonCommercial 4.0 International License (http://creativecommons.org/licenses/by-nc/4.0/) which permits copy and redistribute the material just in noncommercial usages, provided the original work is properly cited. 
In this background, our institution initiated a program of "sustained support" for PG students in researching a dissertation until it is submitted for publication. The components and results of the program are presented in this article.

\section{Objectives}

The purpose of this article was to report the impact of the support program on getting published.

\section{Methods}

This prospective study was conducted on students who registered for the PG admission in 2015 selected using total population sampling $(n=27)$. Our hospital is a 1650bedded, missionary-run, multispecialty, tertiary care hospital serving three districts of central Kerala. Started in 1951, the hospital was transformed into a medical college in 2003. Currently, 15 departments (out of 23 required for undergraduate (UG) courses) run postgraduate (PG) courses with 28 seats in broad specialties. The University regulations make it mandatory for all PG students to submit a research proposal before the close of the first semester and completed work one semester prior to the final University examinations (10). The students have two years to perform research for the dissertation. To support the PG students doing dissertations, programs were planned and conducted from the first semester to the sixth semester (Appendix 1 in File Supplementary). This study was done on students admitted to the 2015 Batch.

The program started in the first semester with an orientation for the guides/co-guides. The topics covered included the need for research, methods to facilitate and monitor research progress, and systematic approaches for reviewing journal articles.

Two programs were conducted for the students. The Research Methodology training for PG students; topics included were developing a research question, methodology, literature search, and statistical analysis. The second was the presentation of the study protocol for critical review by experts (external to the department) and suggestions for improvement.

The mid-second year review was conducted, in which the students were asked to make a presentation on the status so far, about the collected sample, the ease/difficulties faced, and the list of articles/books reviewed. This session was done with the compulsory participation of the guide/co-guide.

There were two programs during the third year at different points. A presentation was again made during the fifth semester. This included a pre-submission presentation with critical inputs by experts (from outside the college), and a cash prize was distributed for the best dissertation. After submission at the beginning of the sixth semester, the students were encouraged to extract a research paper from their dissertation. The student and guide were assigned the task of generating one research paper, selecting a suitable journal, and formatting the paper to suit requirements. A workshop was arranged in the central library using the services of technically qualified staff, where groups of students with their guides performed the submission. The workshop was led by the first author. The students submitted their dissertations in November 2017 and the research paper by March 2018. The publication status until April 2019 was gathered.

\section{Results}

The students and their guides attended these discussions. The participation rate in the orientation for guides to pre-submission review varied from $40 \%$ to $100 \%$ (Table 1). Those who were not present in the allotted time were given another chance to present the matter.

\begin{tabular}{|c|c|c|}
\hline Program & $\begin{array}{c}\text { Number of Invited } \\
\text { Students }\end{array}$ & $\begin{array}{l}\text { Values of } \\
\text { Participated } \\
\text { Students }\end{array}$ \\
\hline $\begin{array}{l}\text { Orientation for } \\
\text { guides }\end{array}$ & 54 & $22(40.74)$ \\
\hline $\begin{array}{l}\text { Research } \\
\text { methodology for } \\
\text { students }\end{array}$ & 28 & $27(96.42)$ \\
\hline $\begin{array}{l}\text { Pre-submission } \\
\text { (synopsis) external } \\
\text { review }\end{array}$ & $27^{\mathrm{b}}$ & $27(100)$ \\
\hline $\begin{array}{l}\text { Mid second-year } \\
\text { review }\end{array}$ & 27 & $26^{\mathrm{c}}(96.29)$ \\
\hline $\begin{array}{l}\text { Pre-submission (final } \\
\text { dissertation) }\end{array}$ & 27 & $26(96.29)$ \\
\hline Selection for award & 27 & $26(96.29)$ \\
\hline $\begin{array}{l}\text { Workshop for paper } \\
\text { submission }\end{array}$ & 27 & $26^{\mathrm{d}}(96.29)$ \\
\hline \multicolumn{3}{|c|}{$\begin{array}{l}\text { a Values are expressed as No. (\%). } \\
{ }^{b} \text { One student discontinued the course. } \\
{ }^{c} \text { One student did not present. } \\
\text { d }\end{array}$} \\
\hline
\end{tabular}

Before appearing for the final university examinations, all 27 students successfully prepared articles from their dissertations. Publication rate was $70.37 \%(n=27)$. Their status with respect to the publication process is detailed in Table 2. All the journals, which published studies of our students, were indexed open access journals satisfying the Medical Council of India (MCI) standards. 


\begin{tabular}{lc}
\hline Table 2. Number of Dissertations and Their Stage in the Publication Process ${ }^{\mathrm{a}}$ \\
\hline Status & Values \\
\hline Number of dissertations completed & $27(100)$ \\
\hline Number of papers generated & $27(100)$ \\
\hline Number of papers submitted to the journals & $27(100)$ \\
\hline Number of papers published & $19(70.37)$ \\
\hline $\begin{array}{l}\text { Number of papers under review } \\
\text { Number of papers rejected but under resubmission to other } \\
\text { journals }\end{array}$ & $7(25.92)$ \\
\hline \begin{tabular}{l} 
a Values are expressed as No. (\%). \\
\hline
\end{tabular}
\end{tabular}

As of 2018, the 2012 Batch, 19 students published two papers, 24 students of 2013 Batch had one publication, and 24 students of 2014 Batch had four publications.

No financial support was given to the students, except for the cash award for the best presentation and subsidized rate for lab investigations. None of the studies were part of any funded projects of any guides.

\section{Discussion}

Our study showed that if sustained support is given to PG students and their guides, extracting research papers from dissertations and submissions to scientific journals is possible. The availability of journals for getting published is not scanty now, though the standards of some of them are doubtful. As it is the beginning of the effort, and PG students are at the beginning of their profession, standards were not insisted. "Let it begin, can prune later" was the policy we adopted. Publications of the faculty independent of the PG dissertations are also in similar journals at present. The next priority will be to encourage submissions to the standard journals, which have to start from submissions by the Faculty.

Researchers should make their results available in the public domain and be accountable for the completeness and accuracy of reports (11). Bullen et al. (12) reported factors hindering students from publishing their findings as lack of time, staff support, and confidence in writing ability (13). They opined that sustained commitment from supervisors, practical support as seminars and workshops, effective supervisor-student engagement, funding, and setting an expectation of publication could improve publication rates of the student, which is consistent with our observations.

It has been reported that "research is a key area of deficiency in our society" (8). In India, as in any low and middle income (LAMI) country, the priority is to achieve universal health care. This requires a lot of investment to reach the entire population. Research is one of the disciplines that require investment without a guarantee of a return. Hence, investment for research in health remains a low priority. However, research in the basic sciences requires heavy investment (for labs, technical experts, and equipment). Clinical research needs comparatively lesser investment in all these areas. Despite this, we rely on clinical data from other countries for evidence-base creation and for developing practice guidelines. Such data is derived from a different genetic pool, with different psychophysiological makeup and socio-cultural backgrounds (6), making it unsuitable for generalization with our population. Data from our populations are sometimes used by scientists from elsewhere to generate or prove hypotheses. Their research questions will be suitable for addressing the problems faced elsewhere, rather than applicable to the actual field of data. Modes and models for universal health care, and making them cost-effective are actual challenges. Perhaps, we are unaware of the research questions, availability of data, and even market potential of translations of the research.

Departments functioning in isolation could be another reason for the poor state of the research in India. Developments in one area could spark a new idea in a different field. For example, lessons from the eradication of stigma associated with tuberculosis can be helpful for addressing the similar stigma associated with mental illnesses. The lack of integrative studies with basic sciences as a component remains a major impediment to innovative research in medical institutions. Encouraging PG dissertations under the joint supervision of basic science scientists and practicing clinicians could overcome this barrier. The research center attached to our medical college has laboratories focused on genetics, biochemistry, and virology. A policy of encouragement in this direction appears promising with likewise projects getting approvals from various funding bodies with interdepartmental collaborations between basic sciences and clinical departments.

Most PG students work under difficult conditions, with long duty hours and an inflexible time limit for completing the research component of their degrees. The ambition of many PG students is to become a busy practitioner, which takes away the emphasis on nurturing research capability. The choice of inconsequential topics leads to a lack of enthusiasm for the students. Each new student works on different topics, instead of extending the theme of the research conducted by previous students. This discontinuity negatively affects the focus on the research, which is required to generate capacity and enthusiasm to penetrate deeper into the subject; which can lead to expertise in the chosen area. Poor support and supervision by 
research guides result in students branding dissertation work as a futile exercise. All these factors could explain presently prevailing disappointing research output (12).

Holding idealism, tradition, solitude, and a low tolerance for failure are considered as parts of Indian culture. Using our own philosophies and theories would be better than copying approaches from elsewhere, which were derived from their principles (10). Observing the comparable pattern of low resources and socio-economic status in India and China, it was opined that "to serve the underserved, use of existing resources and technologies in a flexible manner is the practice and priority" (11).

India has the second largest market in the field of higher education. However, research on higher education is rare and it is non-existent in health care science (13), which may also observe in other LAMI countries. The present study was an attempt to fill that void. During 2005 - 2014, the contributions of Indian social scientists in terms of research output in social science and allied disciplines have increased. However, the average number of citations per document in the later period has declined. At the same time, international collaborations among Indian researchers are increasing in terms of the number of publications (7). These observations point to the need for ensuring quality while focusing on quantity.

While research is mandatory for PG courses, it is totally ignored at the UG level. Writing skills for biomedical publication is also not promoted (8). The concept of research at the UG level needs to be facilitated further. The short-term studentship (STS) program of the Indian Council of Medical Research (ICMR) and also the fellowship for clinicians to take up research careers are some of the possible facilitations (9).

Despite all the hindering factors, a "sustained gentle push" will generate desirable responses from the younger generation of doctors. Based on our observations, this is not an optimistic statement, but a definite possibility. Dhaliwal et al. (5) also indicate that publication success is linked to a superior's supportive role in scientific publishing. Inviting the faculty from other disciplines during presentations has also proved to be advantageous in our case, as has been reported elsewhere (14). The midterm presentation may help students to improve data collection and rectify any flaws in design (15), which also we followed.

Research is essential in solving everyday problems, and addressing local needs, require more practitioners taking up that responsibility, which is more relevant for LAMI countries.

\subsection{Conclusions}

Sustained gentle encouragement and an expectation to publish resulted in significant publication status.

\subsection{Limitations}

We considered the publication status of only one year that can be regarded as one of the limitations of this study. However, this short period helped us in determining the status of all 27 students.

\section{Supplementary Material}

Supplementary material(s) is available here [To read supplementary materials, please refer to the journal website and open PDF/HTML].

\section{Footnotes}

Authors' Contribution: None declared by the authors. Conflict of Interests: The authors declared that they have no conflict of interest.

Funding/Support: None.

\section{References}

1. Munung N, Vidal L, Ouwe-Missi-Oukem-Boyer O. Do students eventually get to publish their research findings? The case of human immunodeficiency virus/acquired immunodeficiency syndrome research in Cameroon. Ann Med Health Sci Res. 2014;4(3):436-41. doi: 10.4103/2141-9248.133474. [PubMed: 24971222]. [PubMed Central: PMC4071747].

2. Salmi LR, Gana S, Mouillet E. Publication pattern of medical theses, France, 1993-98. Med Educ. 2001;35(1):18-21. doi: 10.1046/j.13652923.2001.00768.x. [PubMed: 11123590].

3. Arriola-Quiroz I, Curioso WH, Cruz-Encarnacion M, Gayoso O. Characteristics and publication patterns of theses from a Peruvian Medical School. Health Info Libr J. 2010;27(2):148-54. doi: 10.1111/j.14711842.2010.00878.x. [PubMed: 20565556].

4. Nieminen P, Sipila K, Takkinen HM, Renko M, Risteli L. Medical theses as part of the scientific training in basic medical and dental education: Experiences from Finland. BMC Med Educ. 2007;7:51. doi: 10.1186/1472-6920-7-51. [PubMed: 18053247]. [PubMed Central: PMC2235851].

5. Dhaliwal U, Singh N, Bhatia A. Masters theses from a university medical college: Publication in indexed scientific journals. Indian $J$ Ophthalmol. 2010;58(2):101-4. doi: 10.4103/0301-4738.60070. [PubMed: 20195030]. [PubMed Central: PMC2854438].

6. Kalra S, Kalra B, Pathak V. Indian Medical Research: Encouraging trends. Perspect Clin Res. 2013;4(4):240-1. doi: 10.4103/22293485.120176. [PubMed: 24312895]. [PubMed Central: PMC3835971].

7. Ray S, Shah I, Nundy S. The research output from Indian medical institutions between 2005 and 2014. Current Medicine Research and Practice. 2016;6(2):49-58. doi: 10.1016/j.cmrp.2016.04.002.

8. Indian Council of Medical Research. ules and regulations information desk media room awards NEET. 2020. Available from: https:// oldmciindia.org/informationdesk/collegesCoursesSearch.aspx.

9. Barnwal R. Economics times health world. 2010. Available from: https: //health.economictimes.indiatimes.com/.

10. Chawla B. Medical research in India: Are we there yet? Delhi J Ophthalmol. 2017;28(2). doi: 10.7869/djo.301. 
11. Meo SA, Al Masri AA, Usmani AM, Memon AN, Zaidi SZ. Impact of GDP, spending on R\&D, number of universities and scientific journals on research publications among Asian countries. PLoS One. 2013;8(6). e66449. doi: 10.1371/journal.pone.0066449. [PubMed: 23840471]. [PubMed Central: PMC3688761].

12. Bullen CR, Reeve J. Turning postgraduate students' research into publications: A survey of New Zealand masters in public health students. Asia Pac J Public Health. 2011;23(5):801-9. doi: 10.1177/1010539511417998. [PubMed: 21852423].

13. World Medical Association Declaration of Helsinki. Ethical princi- ples for medical research involving human subjects. 2013. Available from: https://www.wma.net/policies-post/wma-declarationof-helsinki-ethical-principles-for-medical-research-involvinghuman-subjects/.

14. Gitanjali B, Raveendran R. Teaching research methodology to postgraduates: Is dissertation the only method? Natl Med J India. 1998;11(1):23-5. [PubMed: 9557517].

15. Kabra SK, Verma IC. Thesis during MD: Must or bust? Indian J Pediatr. 2007;74(9):868-9. doi:10.1007/s12098-007-0158-Z. [PubMed: 17901682]. 